\title{
POPULATIONS AS DETERMINANT OF LATVIA'S SECURITY
}

\author{
Jan A. WENDT * \\ University of Gdańsk, Institute of Geography, Bażyńskiego 4, 80-309 Gdańsk, Poland, \\ e-mail: jan.wendt@ug.edu.pl
}

Citation: Wendt A. J. (2021). Populations as Determinant of Latvia's Security. Revista Română de Geografie Politică, 23(1), 22-28. https://doi.org/10.30892/rrgp.231103-349

\begin{abstract}
The conducted analysis aims to indicate the real threat of the depopulation process to Latvia's national security. The aim of the analysis is to examine the pace of changes, to indicate their main determinants and potential effects. The research hypothesis assumes that in the absence of an immediate, radical change in the demographic and social policy of the state, the population of Latvia will decrease to the level of approx. 1 million in the next 40-45 years. The conducted research shows a constantly decreasing natural increase and a high, negative level of migration. The carried out extrapolation of the population number confirms the hypothesis put forward in the study. The slight effect of the measures taken so far by the Latvian government to counter the depopolation process does not allow us to put an end to the optimistic scenarios of changes in demographic processes. An additional problem of the country's security is the issue of, above all, the Russian ethnic minority and the almost $10 \%$ share of non-citizens among the country's inhabitants.
\end{abstract}

Key words: demography, Latvia, population, population decline, security

\section{INTRODUCTION}

TThe issue of ensuring security is one of the fundamental needs of every person and society. It is the need for security that forces most creatures to gather, form a group, community, and cooperate. It has been known since prehistoric times that a family / lineage / tribe or nation has a better chance of survival than a single person or a small social group. Nowadays, the category of security is understood very broadly, it refers both to the internal situation of states (national security), as well as from cyber-security to its cosmic conditions in terms of international security (Bógdał-Brzezińska, 2020a; 2020b). Numerous works show the importance of the economy and the country's defense for ensuring security. The fundamental issues for security have become the changing realities of life, techniques, scientific discoveries, changes in political constellations, influence and changes in the geopolitical position, new media, fake news pointing to new spheres (Bógdał-Brzezińska and Wendt, 2020) from which we may face a threat

\footnotetext{
${ }^{*}$ Corresponding Author
} 
(Bełza, 2011). After the end of the period of postmodernity, with the returning role and meaning of the concept of the nation, researchers put more and more emphasis on the narrow concept of security. Narrowed by the adoption / restoration of the concept of the nation and functioning in the literature as national security (Bak, 2010).

In the literature on the subject, you can find numerous works with varying degrees of precision addressing the issue of security (Korzeniowski, 2016), its definition (Stańczyk, 1996), essence (Lutostański, 2017), the theory of threats Lubieński and Dróżdż, 2020), the spatial approach to the phenomenon (Wendt, 2008), its sources, types and classification (Ciekanowski, 2010). On the basis of the latter, social security should be distinguished, which includes issues related to national heritage, education for security, media, social assistance, social security and demography (Gierszewski, 2018, p. 31).

The latter seems particularly interesting in the context of contemporary demographic processes in Europe and in the world. These processes, in the context of threats to security, have already been the subject of numerous studies, which indicate, inter alia, the problem of the aging of the population on the example of Japan (Warchol, 2015), the issues of differentiation of population growth in ethnic terms in Israel (Toft, 2012), the problem of security threats due to the demographic processes taking place in EU countries (Sofer, 2008) or the demographical problems and national security of Poland (Durasiewicz, 2015; Lewicka, 2016). Various research approaches and the importance attached to individual factors characterizing demographic processes deserve a separate study (Baranowski, 2017). In this paper, the starting point is the analysis of M. Łakomy, who indicates the importance of the country's population for its security on the example of Poland (Eaomy, 2016), in order to generalize this issue at the European level (Lakomy, 2017a), concluding its significance for the power of the state (Łakomy, 2017b).

The case of depopulation and the related demographic problems of Poland is a good example in this case, as are the introduced and largely ineffective methods of preventing the progressive decline in the population of Poland. However, more interesting, due to the pace of changes and their consequences for national security, is the issue of Latvia's demographic problems. The Republic of Latvia proclaimed independence in 1918. After a short period of independence, it was incorporated into the Soviet Union (1940), and regained independence after its collapse in 1991. This year, the country's population reached 2,685,000. systematically decreasing to the level of 1,868 thousand in 2021 (Population of Latvia, 2021).

If we take into account the decrease in the number of inhabitants by $30.4 \%$ over the last 30 years, from the point of view of national security, as defined in the works of M. Łakomy (2016; 2017a, 2017b), it seems fully justified to undertake research on the demographics of Latvia. The aim of the analysis is to examine the pace of changes, to indicate their main determinants and potential effects. The research hypothesis assumes that in the absence of an immediate, radical change in the demographic and social policy of the state, the population of Latvia will decrease to the level of approx. 1 million in the next $40-45$ years.

\section{MATERIAL, METHODS AND LIMITATION OF RESEARCH}

The analysis of demographic changes used statistical data characterizing the population of Latvia on the basis of the Latvian statistical year, collected literature on the subject, as well as statistical data and demographic forecasts from the 
Internet portals "Worldometer", "World Population Review", "Eurostat" and "The World Fact Book". The research used statistical methods with the use of simple extrapolation of the population number. In the literature on the methodology of demographic research, we can find several more detailed approaches, such as adaptive forecasting methods (Sojka, 2016), however, T. Wilson and F. Rove indicate that the analyzed methods of studying demographic changes are characterized by a low error difference compared to extrapolation forecasts (Wilson and Rove, 2011). The statistical analysis was supplemented by small-scale works with the use of text analysis and reports on changes in the population of Latvia.

At this point, it is necessary to point out the limitations of the simple extrapolation method used and the entire analysis. In demographic research, it should take into account at least the dimensions including the natural increase rate and factors characterizing the migration processes (Szydłowski et al., 2018; Wendt et al., 2018). In the case of the conducted analysis, a simplification was adopted, focusing on indicators describing only the total dimension of these two processes, without their detailed analysis. This simplification allows for a clear indication of the emerging trend and the result of the extrapolation performed. They can be treated as an introduction to the development of a detailed analysis of demographic changes in Latvia, but such a holistic study goes far beyond the accepted research framework. Another limitation of the proposed research is the lack of a detailed analysis of economic and social issues influencing demographic processes. The multifaceted approach to this issue also goes far beyond the adopted research objective and is not a necessary condition for the verification of the presented hypothesis.

The last limitation of this analysis is the nationality issues, which are very important in the case of Latvia. They are important because national minorities in Latvia constitute, according to various sources, almost 37.5\%. Latvians are 62.5\%, while, for example, Russians living in Latvia are $24.7 \%$ (Latvian data) (Demography 2020, 2020). However, according to the CIA World Fact Book, Latvians are slightly less, 62.2\%, and Russians are 25.2\% (World Fact Book, 2021). The remaining almost $13 \%$ of Latvia's inhabitants belong to the Belarusian, Ukrainian, Lithuanian and Polish ethnos, respectively. What is significant, the official Latvian language in Latvia is spoken by only $56.3 \%$ of the inhabitants, while Russian as much as 33.8\% (World Fact Book, 2021). From the point of view of citizenship, in 2021 Latvian citizenship was held by $86 \%$ of the country's population. As many as $10 \%$ of the country's inhabitants have the status of a noncitizen, $2 \%$ have the citizenship of the Russian Federation, and the rest have citizenship of other countries (Demography 2020, 2020, p. 12). Such a small share of the indigenous Latvian population is another factor that threatens the national security of the country.

\section{RESULT AND DISCUSSION}

The demographic changes after Latvia regained independence document a steady decline in the population. From 2.67 million (1990) to 1.91 million (2020). Such a significant decrease in the population by $28 \%$ in the analyzed period (Figure 1) poses a threat not only to national security, but with the initial data values for the absolute number of population, it may even threaten the biological existence of the Latvian ethnos. It seems obvious, but due to the importance of the issue, it should be emphasized that reducing the population by more than $1 / 4$ of the population is always a threat to its security. However, it is one thing for a 
population decline to decline for a population of several million, and another for a population of two and a half million, with more than $35 \%$ of non-Latvian ethnic minorities among them. In 2020. the population of Latvia was $1,908,000$, but the Latvians and Liwons, i.e. the indigenous inhabitants of the country, are only around $62.5 \%$, which is $1,193,000$. This is not geographic determinism or social Darwinism, but a simple observation based on statistics.

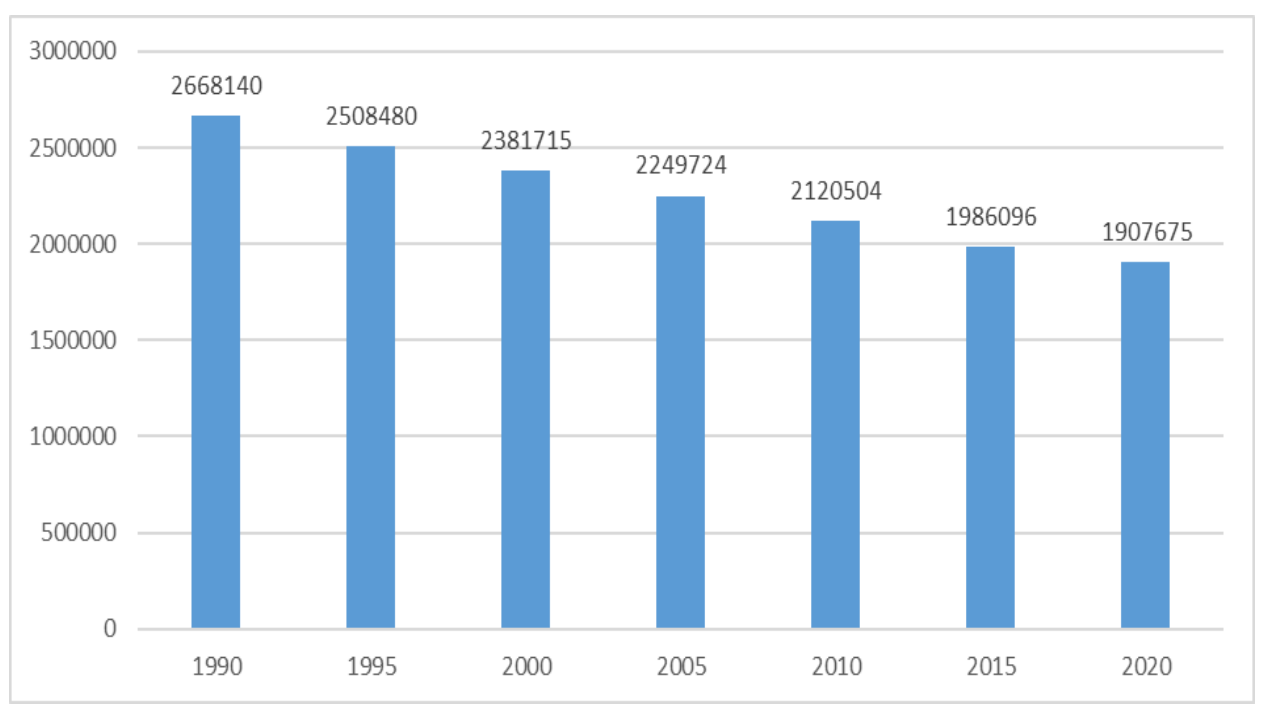

Figure 1. Decline in the population of Latvia in 1990-2020

(Source: Demography 2020. Collection of statistics (2020). Central Statistical Bureau of Latvia, Riga, p. 6 and Eurostat)

As can be concluded from the literature on the subject, the main reasons for such a significant decrease in the number of people are the decreasing natural increase, the aging of the population and the high negative migration level (Heleniak, 2006). Since the beginning of the nineties, the population of Latvia has been showing a downward trend and all forecasts confirm its maintenance (Republice of Latvia, 2018). Since regaining independence, Latvia has lost over $25 \%$ of its population, of which about $60 \%$ is caused by emigration from the country. In conjunction with the negative natural increase, the quoted report indicates that the country's population will decrease to 1.5 million in 2050. An additional threat to social security is the increasing average age of the population and the growing pension dependency ratio. In the years 1990-2015, the average age increased from 35 to 43 years, and in 2050 growth is expected to 46 years. The retirement dependency ratio is also changing rapidly. The proportion of the population aged $65+$ to the population aged 15-64 was $18 \%$, and in 2050 it was is to be $48 \%$ (Republic of Latvia, 2018, p. 16). Already in 2030. every fourth inhabitant of Latvia will be over 65 years of age (Auers and Gubins, 2017).

According to the World Population Review portal, the population of Latvia as of April 20, 2021 was 1,869,074 people. This statistical portal indicates that 53 children are born daily in the country, 76 people die, which already gives a negative birth rate of -23 people. If we add after the same source that net migration is negative and amounts to 29 people a day, we get a daily decrease in the population of Latvia estimated at 52 people, which means almost 18,980 
people per year. Simple mathematical operations show that statistically speaking, the number of inhabitants of the country decreases by one person every 28 minutes. Importantly, the data provided by the portal correspond to a large extent with the data from the country's statistical year (table 1) and the estimated UN data. The high emigration additionally contributed to the decreasing number of births and the increasing deaths. As a result of the economic recession of 20082012 , a relatively large number of young people decided to leave the country and seek better living conditions abroad. The economic policy pursued by the Latvian government has led to a decline in wages, an increase in unemployment and a reduction in domestic investment. Which strengthened the migration trends, strong after Latvia's accession to the EU and the opening of labor markets, the socalled countries of the "old EU" to migrants from the new member states. Estimates indicate the number of migrants per 200,000. people until 2011 (Kajaks, 2013).

Table 1. Changes in population growth and migration in Latvia in 1990-2019 (Data source: Own study based on Demography 2020. Collection of statistics (2020). Central Statistical Bureau of Latvia, Riga; Worldometers; World Population Review)

\begin{tabular}{|c|c|c|c|c|c|c|c|}
\hline \multirow{2}{*}{ Year } & \multicolumn{3}{|c|}{ Natural increase } & \multicolumn{3}{c|}{ Migration } & \multirow{2}{*}{$\begin{array}{c}\text { Total } \\
\text { balance }\end{array}$} \\
\cline { 2 - 8 } & Births & Deaths & Balance & Immigration & Emigration & Balance & -11939 \\
\hline $1990^{*}$ & 37918 & 34812 & 3106 & 14684 & 29729 & -15045 & -13713 \\
\hline 1995 & 21595 & 32777 & -11182 & 2799 & 16512 & -24895 \\
\hline 2000 & 20302 & 32205 & -11903 & 6483 & 22911 & -16428 & -28331 \\
\hline 2005 & 21879 & 32777 & -10898 & 6691 & 17643 & -10952 & -21850 \\
\hline 2010 & 19781 & 30040 & -10259 & 4011 & 39651 & -35640 & -45899 \\
\hline 2015 & 21979 & 28478 & -6499 & 9479 & 20119 & -10640 & -17139 \\
\hline 2019 & 18786 & 27719 & -8933 & 11223 & 14583 & -3360 & -12293 \\
\hline
\end{tabular}

*1991 for migration.

Given the current pace of population decline and the net migration, although declining, but still having a negative value, it should be expected that the current trend of population decline may weaken, but will still continue. Taking into account that the statistical number of children per one woman of childbearing age in Latvia is only 1.27 , which by no means ensures the stabilization of the population number and clearly indicates its decline. Research carried out by Latvian demographers shows that the reaction of the Latvian government is weak or even absent to prevent the real danger (Tsaurkubule, 2017). Apart from mostly declarative programs, no real actions have been taken to create attractive conditions for young, educated people, some of whom eventually migrate from the country. Changes in education, including an increasing number of people with higher education, will also favor lower fertility and migration rather than stay in the country and increase the fertility rate.

A simple extrapolation, based on the assumption of the stability of the current trend, allows to estimate that with the population decline rate by 18,980 per year and the starting point in April 2021 the population of Latvia $(1,869,000)$ will decrease to about 1 million in less than 46 years, i.e. in 2067. However, it should be borne in mind that the rate of decline of the decreasing population may increase for obvious biological reasons. From a demographic perspective, a decreasing number of children will have an impact on a declining number of births with a persistent or increasing number of deaths of older people. The given value correlates well with the results of the research by $Z$. Tsaurkubule (2017), 
who forecasts a decrease in the population of Latvia by half from the level of $1,986,000$. to the level of 1 million in 40 years, that is already in 2057 (Tsaurkubule, 2017, p. 163), which confirms the thesis about the increase in the rate of decline of the population of Latvia along with its decline.

\section{CONCLUSION}

To sum up, the undertaken analysis of demographic changes made it possible to study the pace of population processes taking place in Latvia. The downward trend is definitely permanent, the decrease in the number of people in the analyzed period reaches over 30\%, from approx. 2.7 million (1990) to 1.9 million (2020) and 1.867 million in April 2021. The main factors influencing the decline in the population number are the constant negative natural increase and the very high, negative level of the net migration.

The ongoing changes already have a negative impact on the country's economy, and their continuation will lead to a threat to both economic (workforce) and social security (the pension dependency ratio) and may actually threaten the existence of the Latvian nation in the perspective of the end of this century. The research hypothesis has been positively verified. With a high degree of probability, confirmed by the results of other studies cited and analyzed in this study, the population of Latvia, in the absence of real actions by the Latvian government, will decrease to the level of 1 million in the next 40-45 years.

The last conclusion does not result directly from the conducted analysis, but it is a logical consequence resulting from the collected data and the limitations of the research indicated in the study. Assuming that Latvians constitute only $63 \%$ of the country's population, their number will drop to around 630,000. in about 40-45 years. Which is another threat to national security that deserves a separate analysis.

\section{REFERENCES}

Auers, D., Gubins, S. (2017). A demographic portrait of Latvia today ... and tomorrow. Policy Brief, 3, Domnica Certus: Riga.

Baranowski, P. (2017). Współczesne wyzwania demograficzne jako determinanty bezpieczeństwa. Teologia i Moralność, 12, 1(21), 135-150. http://dx.doi.org/10.14746/tim.2017.21.1.8

Bąk, M. (2010). Determinanty bezpieczeństwa narodowego. Nowe zagrożenia - nowe wyzwania. Przeglad Politologiczny, 2, 39-44.

Bełza, L. (2011). Główne zagrożenie w obecnym i przyszłym środowisku bezpieczeństwa pozamilitarnego. Bezpieczeństwo Narodowe, 18, 121-137.

Bógdał-Brzezińska, A. (2020). Cyberprzestrzeń $i$ przestrzeń kosmiczna jako sfery bezpieczeństwa międzynarodowego - aspekty teoretyczne. In: M. Jurgilewicz, M. Delong, K. Michalski, W. Krztoń (Eds.), Wyzwania bezpieczeństwa w XXI wieku, Oficyna Wydawnicza Politechniki Rzeszowskiej: Rzeszów, 129-142.

Bógdał-Brzezińska, A. (2020). Mocarstwowość kosmiczna i cybernetyczna jako komponent zmian w obszarze bezpieczeństwa międzynarodowego. In: P. Bajor (Ed.), Bezpieczeństwo międzynarodowe. Aspekty metodologiczne i systemowe, Wydawnictwo UJ: Kraków, 122-139.

Bógdał-Brzezińska, A., \& Wendt, J.A. (2020). Geopolityczny kontekst suwerenności informacyjnej Rosji w cyberprzestrzeni i jej znaczenie dla bezpieczeństwa międzynarodowego. De Securitate et Defensione. O Bezpieczeństwie i Obronności, 2(6), 97-113.

Ciekanowski, Z. (2010). Rodzaje i źródła zagrożeń bezpieczeństwa. Bezpieczeństwo i Technika Pożarnicza, 1, 29-46.

Demography 2020. Collection of statistics (2020). Central Statistical Bureau of Latvia, Riga.

Durasiewicz, A. (2015). Bezpieczeństwo demograficzne na przykładzie wybranych krajów - implikacje dla Polski. In: M. Leszczyński, M. Kubiak (Eds.), Polityka społeczna dla bezpiecznego rozwoju, IP UG, Gdańsk, 191-207.

Eurostat, https://ec.europa.eu/eurostat/databrowser/view/demo_pjan/default/table?lang=en, 
accessed on 11.04.2021.

Gierszewski, J. (2018). Bezpieczeństwo społeczne jako dziedzina bezpieczeństwa narodowego. Historia i Polityka, 23(30), 21-38. http:/ /dx.doi.org/10.12775/HiP.2018.002

Heleniak, T. (2006). Latvia Looks West, But Legacy of Soviets Remains. Migration Information Source, 01.02.2006, https://www.migrationpolicy.org/article/latvia-looks-west-legacy-sovietsremains, accessed on 11.04.2021.

Kajaks, J. (2013). Study on the economic and social situation in the Baltic States Latvia. European Economic and Social Committee: Brussel.

Korzeniowski, L.F. (2016). Securitologia Nauka o bezpieczeństwie człowieka i organizacji społecznych. Uniwersytet Pedagogiczny im. KEN: Kraków.

Lewicka, D.A. (2016). Bezpieczeństwo demograficzne państwa - implikacje dla Polski. Rocznik Bezpieczeństwa Międzynarodowego, 10(2), 273-281.

Population of Latvia (1960-2021) (2021). https://www.populationof.net/pl/latvia/

Lubieński, P., \& Dróżdż, A. (2020). Zagrożenie - rozważania na gruncie teorii. Zeszyty Naukowe PWSZ w Legnicy, 34(1), 77-87.

Lutostański, M. (2017). Bezpieczeństwo i jego istota. Refleksja terminologiczna. Przedsiębiorczość $i$ zarzadzanie, 18(5), 163-177.

Łakomy, M. (2016). Demografia polityczna i możliwości dla polityki pronatalistycznej w Polsce. Studia Demograficzne, 169(1), 65-91.

Łakomy, M. (2017a). Bezpieczeństwo demograficzne Europy w XXI wieku. Przeglad Geopolityczny, 21, 31-47.

Łakomy, M. (2017b). Bezpieczeństwo demograficzne a potęga państw. Przegląd Geopolityczny, $19,124-141$.

Republic of Latvia. Selected issues (2018). IMP Country Report, 18(267), September 2018.

Sofer, A. (2008). The Connection between Demography and National and International Security - The Case of the E.U. National Security and the Future, 1-2(9), 9-23.

Sojka, E. (2016). Adaptacyjne metody prognozowania w demografii. Studia Ekonomiczne, 270, $252-264$.

Stańczyk, J. (1996). Współczesne pojmowanie bezpieczeństwa. ISP PAN: Warszawa.

Szydłowski, J., Wilk, D., \& Wendt, J.A. (2018). Wpływ migracji na rozprzestrzenianie się chorób na przykładzie Niemiec. Zeszyty Naukowe Politechniki Ślaskiej, Seria Organizacja i Zarzadzanie, 126, 197-208.

The World Fact Book, 2020, (2021). CIA. https://www.cia.gov/the-world-factbook/countries/latvia/, accessed on 15.04.2021.

Toft, M.D. (2012). Demography and national security: The politics of population shifts in contemporary Israel. International Area Studies Review, 15(1), 21-42.

Tsaurkubule, Z. (2017). Demographic policy of Latvia: problems and prospects. Prace Naukowe Uniwersytetu Ekonomicznego we Wrockawiu, 465, 156-165. http://dx.doi.org/10.15611/pn.2017.465.17

Warchol, P. (2015). Zmiany demograficzne jako zagrożenie dla bezpieczeństwa. Analiza na $\begin{array}{llll}\text { przykładzie Japonii. } & \text { Przeglad } & \text { Strategiczny, } & \text { 345-360. }\end{array}$ http:/ / dx.doi.org/10.14746/ps.2015.1.23

Wendt, J. (2008). Zarys współczesnych zagrożeń $w$ wymiarze globalnym, regionalnym i lokalnym. W: T. Michalski (Ed.), Zagrożenia we współczesnym świecie jako temat edukacji geograficznej, WSiP: Warszawa, 7-11.

Wendt, J.A., Lewandowska, I., \& Wiskulski, T. (2018). Migranci ukraińscy w Polsce w latach 2014 2017. Zeszyty Naukowe Politechniki Ślaskiej, Seria Organizacja i Zarzadzanie, 126, 223-236.

Wilson, T., \& Rowe, F. (2011). The forecast accuracy of local government area population projections: a case study of Queensland. Australasian Journal of Regional Studies, 17(2), 204-243.

World Population Review, (2021). https://worldpopulationreview.com/countries/latvia-population, accessed on 15.04.2021.

Worldmeters, (2021). https://www.worldometers.info/world-population/latvia-population/, accessed on 15.04.2021.

Submitted:

April 29, 2021
Revised:

Mai 20, 2021
Accepted and published online: Mai 25, 2021 